\title{
THE COMMERCIAL BANKS' CREDIT RISK EFFICIENCY: EMPIRICAL EVIDENCE FROM KOSOVO
}

\author{
Arbana Sahiti \\ University of Prishtina “Hasan Prishtina”, Prishtina, Kosovo \\ Arben Sahiti \\ University of Gjilan “Kadri Zeka”, Gjilan, Kosovo
}

\begin{abstract}
Commercial banks' credit risk management is a function that focuses on events that may affect the achievement of objectives. Improper management will result in negative consequences or results. Therefore, banks usually pay more attention to events with a higher probability and impact of a direct loss of revenue and capital than events that may result in positive effects. This research adopts secondary data and seeks to analyze credit risk management of commercial banks in Kosovo through a developed DEA (Data Envelopment Analysis) model. The study covers seven commercial banks in Kosovo for the period 2008-2016 and uses Tobit regression to determine credit risk efficiency. The estimation results show a statistically significant positive relationship between bank efficiency, capital adequacy, and loans. Moreover, the study found that banks' efficiency factors, including profitability, deposits, costs, bank size, GDP growth, and inflation, are not statistically significant
\end{abstract}

Keywords: risk management, creditor, commercial banks, capital, bank efficiency

DOI: http://dx.doi.org/10.15549/jeecar.v8i2.635

\section{INTRODUCTION}

Kosovo's banking system is relatively new. It was established after the war period of 1999 , along with other institutions. So far, it has gone through an incredible path, given that Kosovo's success story and its economic transformation from a war-torn country are closely related to the country's financial development. Banks in Kosovo play a significant role in the financial system. To date, banks have provided generous contributions in creating jobs, the process of development and economic growth, and in the investments field. Banks provide the bulk of the money supply, offering credit facilities (Omankhanlen, Alex, 2012). They also serve as a mechanism for developing the country's monetary policy (Peek \& Rosengren, 2012). To play an essential role in the economic system, banks must be efficient in transforming the inputs and outputs of financial products and services. According to Adusei (2016), only healthy, technically efficient, and profitable 
banks can promise a real return on investment and reduce bankruptcy probability. Due to the rapid changes in the global financial market, bank managers, investors, and regulators place great importance on expensive inputs of financial products and services (Isik \& Hassan, 2002). So economic efficiency is an essential issue as it enhances financial sustainability (Blejer, 2006).

Even though prior research has been done on banks' performance in the field of credit risk efficiency in other countries, there is still an empirical gap regarding credit risk efficiency issues in the banking system, especially in Kosovo. This study addresses the banks' efficient methods of assessing credit risk efficiency by combining financial reports with the DEA model. This research aims to show credit risk preferences, bank performance, and applied techniques. This paper will contribute to the literature by comparing cost-effectiveness and technical allocation efficiency. The empirical results are of great interest both for scientific research and for application in everyday life, especially in an emerging nation.

The paper's structure consists of the following sections: Introduction, literature review, methodology, data selection of variables, analysis, results, and conclusion.

\section{LITERATURE REVIEW}

The banking system in recent years has shown that it is not immune to financial and economic crises. Difficult situations similar to the financial crisis of 2007-2009 have increased the need to consider further protective measures in order to minimize the risk and potential losses in the banking sector. The introduction of Basel III regulations on banking supervision across the world on a voluntary basis was of the immediate need to enhance supervision to strengthen regulations to better manage risk in the financial sector. New guidelines on capital requirements, leverage ratios, and liquidity ratios are the main components of the Basel III regulatory framework to enhance investors' confidence and strengthen the capability of financial institutions to handle any possible market hit (Allen et al., 2012). Implementation of Basel III requirements aims to diminish the systematic risk by increasing the capacity to absorb losses from potential failure that might occur in the future.

Banks operating in Kosovo have been continuously very conservative by implementing thorough measures to ensure high-profit margins, sufficient liquidity, and overall low levels of bad debts. Despite the relatively good success of Kosovo's banking sector, implementation of the Basel III requirements remains quite challenging not only for Kosovo but also the regional countries as well (Mehmeti, 2020), given the need for capital to support sustainable economic development.

Prior research regarding credit risk efficiency in other countries around the world has shown mixed empirical results, but currently, there are no studies on Kosovo in this particular field. This research area has not been explored to date in Kosovo. Consequently, the fulfillment of this gap is intended to be achieved through this empirical study. The findings that derive from this study will be of paramount importance for investors, policymakers and will shed some light on the situation regarding the performance of the banking system in Kosovo from a perspective that has not been addressed so far.

Altunbaş, Gardener, Molyneux, \& Moore (2001) have pointed out that credit quality is critical in competition, macroeconomics, and financial oversight. According to Jiménez and Saurina (2006), low credit quality expresses the risk signal that may cause more volatility in total loans related to the backward links with the banking system itself. Credit quality is also an essential objective for regulators. It maintains financial stability, so Basel's focus is on banking systems oversight, which explicitly notes that banks should adopt sound credit risk management practices and capital appreciation sufficiency. Through effective credit risk management, banks create their sustainability and profitability and contribute to the system stability and effective allocation of capital in the economy (Psillaki, Tsolas, \& Margaritis, 2010). Moreover, we can say that credit quality is one of the most critical factors for the bank's rate, leading to cost-efficient use of capital. Still, on the other hand, low quality can lead to the deterioration of the banking institution.

Approximately 95\% of bank efficiency studies are concentrated in developed countries, where 
$70 \%$ are in the USA (Berger \& Humphrey, 1997). Most researchers suggest that more research be done on benchmarking and measuring efficiency across countries to ensure financial stability (Ben Rejeb \& Boughrara, 2013; Berger \& Humphrey, 1997; Eichengreen \& Baldwin, 2008). Berger \& Humphrey (1997) have measured and evaluated the technical, allocative, and costefficiency of conventional banks using countrybased data. These authors have found the following explanations for efficiency: it can help government policy, identify economic conditions that create inefficiencies, and improve managerial performance. According to Toçi (2009), the study of southeast European banks' efficiency with particular preference in Kosovo 2002-2005 using the DEA technique has concluded that these banks have shown inefficiencies due to cost and inefficient lending rate. The central banks in the region had put in place regulations to slow the rapid expansion of credit.

In the study of the technical efficiency of the Malaysian banking system by Saha, Ahmad, \& Dash (2015) from 2005-2012, the findings concluded that size, capital, and profit are positively related to efficiency, while expenditures and non-performing loans have a negative relation to efficiency. There are many aspects to which credit risk is measured through bad loans, non-performing loans, and loan loss provisions, which are also related to credit efficiency. Many credit risk assessment techniques are used. They include operational, statistical research methods, linear and quadratic programming, and data envelopment analysis (DEA). Much of this literature has focused on financial factors, profitability, and risk assessment in the capital structure (Altman \& Saunders, 1997). An essential feature of these studies is evaluating credit risk control efficiency as an environmental variable that affects banks' performance (Berger and Humphrey, 1997).

Isik and Hassan (2002b) studied the degree of technical efficiency of allocating the Turkish banking sector to conventional banks for 19881991. This study used the non-parametric approach; DEA is a parametric economic boundary (EFA) approach that shows efficiency measurement. The results show that conventional banks in Turkey have more technical inefficiency than allocative efficiency. Also, in this study, they found that foreign banks operating in Turkey are more efficient than domestic banks. Pasiouras (2008) also used data envelopment analysis (DEA) to study the efficiency of the Greek commercial banking system over 2000-2004. Its results show that loan loss provisions increase the efficiency results while off-balance sheet items do not significantly impact. The differences between efficiency outcomes obtained through profit orientation and mediation approaches are generally small (Pasiouras, 2008a)

\section{DATA AND METHODOLOGY}

Data envelopment analysis (DEA) was first developed by Farrell and expanded by Charnes with co-authors who have elaborated on the technical efficiency link and production limits (McCue \& McCue, 2015). DEA is a nonparametric method by which performance evaluation is performed between decisionmaking groups (DMUs) (Liu et al., 2013). Since this method is considered one of the most efficient ways, it was reasonable to use this econometric model in the study. The DEA model is a mathematical programming technique that measures decision-making units' efficiency (DMUs) compared to other similar DMUs that lie at or below the efficiency limit. Based on the linear program, the efficiency measurement results are calculated from 0 to 1 . Many empirical studies have applied the DEA model to measure bank efficiency by evaluating Technical Efficiency (T.E.), Allocation Efficiency (A.E.), and Cost Efficiency (C.E.). Some other studies have used financial ratios based on earnings, return on equity (ROE), return on assets (ROA), the average expenditure per employee, and earnings per share (EPS).

Technical efficiency (T.E.) measures the proportional reduction in input use if the bank operates efficiently. In contrast, allocation efficiency (A.E.) measures a proportional decrease in cost in the bank's fair allocation of inputs. Cost efficiency (C.E.) is equal to technical efficiency (T.E.) and allocative efficiency (A.E.), which is presented as

$$
\mathrm{CE}=\mathrm{AE}^{*} \mathrm{TE}
$$

With the intermediation method, banks are 
transformers of funds and deposits in loans (George Assaf, Matousek, \& Tsionas, 2013).
Selected inputs and outputs for this study are as follows:

Table 1 Input and output variables used In Dea analysis.

\begin{tabular}{|lc|l|}
\hline \multicolumn{1}{|c|}{ Inputs } & \multicolumn{1}{c|}{ Description } \\
\hline Ratio of total loans to total assets & $(\mathrm{X} 1)$ & Total Loans / Total Assets \\
\hline Ratio of deposit reserve to total deposits $\quad(\mathrm{X} 2)$ & $(\mathrm{X} 3)$ & Deposit Reserve / Total Deposits \\
\hline Credit report overdue & Overdue Loans / Total Loans \\
\hline \multicolumn{1}{|c|}{ Outputs } & $(\mathrm{Y} 1)$ & Net Income / Share Capital \\
\hline Return on equity & Price of inputs & Net Income / Total Assets \\
\hline Return on assets (Px1) & Personnel Costs / Total Assets \\
\hline Price of labor & $(\mathrm{Px} 2)$ & $\begin{array}{l}\text { Personnel Expenses + Non-Interest } \\
\text { Expenses / Total Assets }\end{array}$ \\
\hline Price of physical capital & $(\mathrm{Px} 5)$ & $\begin{array}{l}\text { Total Interest Expense on Deposits / } \\
\text { Total Deposits }\end{array}$ \\
\hline Price of funds & \\
\hline
\end{tabular}

Source: Chen \& Pan, 2012

To evaluate the efficiency for each DMU, we use the DEA model. Assuming the DMUs $(=1,2$, ..., n) within a sample, they have the same approach and the same transformation technology of a vector. In addition to a numerical value in inputs $\mathrm{m}(; \mathrm{i}=1,2, \ldots, \mathrm{m})$ and in the output vector $s(; r=1,2, \ldots, s)$. So, the efficiency of each DMU can be expressed in this way.

$e_{j}=\sum_{i=1}^{n} v_{i} \mathrm{x}_{i j} / \sum_{r=1}^{s} u_{r} y_{r j}$,

$v_{i}$ - represents the inputs;

$u_{r}$ represents outputs (respectively represent the multiplication of outputs and inputs where outputs associate with the CCR-DEA model giving the formula):

$$
\begin{aligned}
& \text { Max } e_{j k}=\varphi_{j k} \\
& \text { s.t. } \sum_{j=1}^{m} \delta_{j} \varphi_{i j} \leq \mathrm{x}_{i j k}, \mathrm{i}=1,2 \ldots, \mathrm{m} \\
& \varphi_{j k} \mathrm{y}_{r j k} \leq \sum_{j=1}^{n} \delta_{j} \mathrm{y}_{r j}, \mathrm{r}=1,2 \ldots, \mathrm{s} \\
& \delta_{j} \geq 0
\end{aligned}
$$

Saha et al. (2015) and Ismail et al. (2013) used a two-stage approach to assess bank efficiency determinants. In the first step, the efficiency results are estimated using the DEA method. In contrast, in the second step, the DEA model results are used to identify and determine the efficiency of the products as dependent variables in Tobit regression analysis.

Tobit regression analysis is often used in various fields to analyze data that has a censored response. The Tobit regression model is a latent linear regression model. There is a parameter that is unknown and dimensional, an explanatory covariate in length, and a random error term (Ding et al., 2017). The results obtained under the DEA model make the variables limited because they vary between the interval 0 and 1 , so we use the Tobit model because it can handle the characteristics of the distribution of efficiency measures by providing results that can provide guidance and an important policy to improve performance in this regard. A censored regression of the Tobit model can be described as follows for the bank.

$$
\mathrm{Yn} *=\beta \mathrm{Xn}+\mu \mathrm{n}
$$

Being submissive $\mathrm{Yn}=\mathrm{Yn} * \quad$ where $\mathrm{Yn} * \geq 0$ different $Y n * \leq 1$

$\beta$ - indicates the set of parameters to be measured, whereas Xn - shows the explanatory vector and $\mu \mathrm{n}$ - indicates the possibility of error. 
$\mathrm{Yn}^{*}$ is a latent variable while $\mathrm{Yn}$ - represents the efficiency results for banks.

Table 2. Dependent and independent variables used in regression analysis

\begin{tabular}{|l|l|}
\hline Dependent variables & \multicolumn{1}{|c|}{ Description } \\
\hline T.E. & Technical efficiency results from DEA \\
\hline CE & Cost efficiency results from DEA \\
\hline AE & DEA allocation efficiency results \\
\hline Independent variables & \\
\hline Internal determinants & \\
\hline Profitability & Return on assets \\
\hline Capital adequacy & Total capital / total assets \\
\hline Expenses & Personnel expenses and not interest / total assets \\
\hline Deposit & Total deposit / total assets \\
\hline Loan & Total loans / total assets \\
\hline Credit Quality (KJP) & Non-performing loans / total loans \\
\hline Size & The Logarithm of total assets \\
\hline External determinants & \\
\hline GDP growth & Annual GDP growth (\%) \\
\hline Inflation & An annual increase of consumer price index (\%) \\
\hline
\end{tabular}

Source: (Batir et al., 2017)

Based on these variables we have constructed the Tobit regression model which is:

$\theta i t=\beta 0+\beta 1 \mathrm{ROA}+\beta 2 \mathrm{ROE}+\beta 3 \mathrm{EXP}+\beta 4$ depos. $+\beta 5$ Loans $+\beta 6 \mathrm{KJP}+\beta 7$ size $+\beta 8 \mathrm{GDP}+$ $\beta 9 \operatorname{Infl}+\varepsilon$

$\Theta$ - represents efficiency (T.E., C.E., A.E.) as a dependent variable, while $\beta 0$ is constant, whereas $\beta 1$ and $\beta 9$ represent the independent variables and $\varepsilon$ is the error term.

\section{DESCRIPTIVE ANALYSIS OF CREDIT RISK EFFICIENCY IN THE KOSOVO BANKING SYSTEM}

Descriptive statistics are about categorizing and describing data. In the data field, we look for valuable relationships in information or models, especially those that can be used (Chauhan \& Kaur, 2015). Descriptive analytics is also seen as a logical or complementary extension to data extraction, providing meaningful insights supporting prediction and impact (Chauhan \& Kaur, 2015). Table 3 presents the descriptive statistics showing the average and standard deviation of the outputs, inputs, and price of inputs. These results are used in the DEA. Based on this table, we see that Return on Equity (Y1) has followed an increase from 2013 from 0.088 to 0.193 in 2016 with an average standard deviation of 0.06. Return on Assets (Y2) during 2008 has been negative as some banks have operated at a loss. Also, from 2013-2016, there has been an increase in return on assets from 0.009 to 0.023 . So it can be seen that there is a $100 \%$ increase in return on equity and return on assets in these two options. Based on these data, we consider that banks have had high profitability during this period.

The mean inputs and standard deviation at $\mathrm{x} 1$ (ratio of total loans to total assets) and $\mathrm{x} 2$ (ratio of deposit reserve to total deposits) show no significant differences among banks during this period. Comparing the values presented in the table, we see a slight increase in non-performing loans during 2008 -2016 from 0.034 to 0.0424 with an average of 0.0210 and a standard deviation of 0.027083 . 
Table 3. Descriptive statistics for input and output variables in Dea analyses.

\begin{tabular}{|c|c|c|c|c|c|c|}
\hline & \multicolumn{2}{|c|}{2008} & \multicolumn{2}{|c|}{2009} & \multicolumn{2}{|c|}{2010} \\
\hline Variables & Mean & $\begin{array}{l}\text { Standard } \\
\text { deviation }\end{array}$ & Mean & $\begin{array}{l}\text { Standard } \\
\text { deviation }\end{array}$ & Mean & $\begin{array}{l}\text { Standard } \\
\text { deviation }\end{array}$ \\
\hline Return on equity (y1) & 0.07142 & 0.12276 & 0.03177 & 0.20369 & 0.03689 & 0.09761 \\
\hline Return on assets (y2) & -0.0045 & 0.04548 & 0.00405 & 0.01751 & 0.00395 & 0.01046 \\
\hline $\begin{array}{l}\text { Ratio of total loans to } \\
\text { total assets (x1) }\end{array}$ & 0.64357 & 0.28265 & 0.70957 & 0.0876 & 0.02805 & 0.07421 \\
\hline $\begin{array}{l}\text { Ratio of deposits } \\
\text { reserve to total } \\
\text { deposits }(\mathrm{x} 2)\end{array}$ & 22094 & 0.23781 & 0.15647 & 0.05884 & 0.03153 & 0.08342 \\
\hline $\begin{array}{l}\text { Credit report overdue } \\
\text { (x3) }\end{array}$ & 3474 & 0.02104 & 02845 & 0.00858 & 0.00433 & 0.01145 \\
\hline Labor price (Px1) & 0.02664 & 0.01422 & 0.02476 & 0.00831 & 0.00357 & 0.00944 \\
\hline $\begin{array}{l}\text { Physical capital price } \\
\text { (Px2) }\end{array}$ & 0.06949 & 0.04817 & 0.06507 & 0.02408 & 0.00835 & 0.02208 \\
\hline \multirow[t]{2}{*}{ Fund price (Px3) } & 00226 & 0.008 & 0.02574 & 0.0061 & 0.00221 & 0.00586 \\
\hline & \multicolumn{2}{|c|}{2011} & \multicolumn{2}{|c|}{2012} & \multicolumn{2}{|c|}{2013} \\
\hline Variables & Mean & $\begin{array}{l}\text { Standard } \\
\text { deviation }\end{array}$ & Mean & $\begin{array}{l}\text { Standard } \\
\text { deviation }\end{array}$ & Mean & $\begin{array}{l}\text { Standard } \\
\text { deviation }\end{array}$ \\
\hline Return on equity (y1) & 0.10504 & 0.10351 & 0.0184 & 0.20146 & 0.0886 & 0.06741 \\
\hline Return on assets (y2) & 0.00984 & 0.01002 & 0.00473 & 0.01751 & 0.00955 & 0.00867 \\
\hline $\begin{array}{l}\text { Ratio of total loans to } \\
\text { total assets }(\mathrm{x} 1)\end{array}$ & 0.72731 & 0.09684 & 0.66834 & 0.11718 & 0.6496 & 0.12726 \\
\hline $\begin{array}{l}\text { Ratio of deposits } \\
\text { reserve to total } \\
\text { deposits }(\mathrm{x} 2)\end{array}$ & 0.12503 & 0.04299 & 0.15874 & 0.06119 & 0.15887 & 0.06841 \\
\hline $\begin{array}{l}\text { Credit report overdue } \\
\text { (x3) }\end{array}$ & 0.02496 & 0.00723 & 0.02641 & 0.01626 & 0.03076 & 0.01999 \\
\hline Labor price (Px1) & 0.02318 & 0.01023 & 0.02237 & 0.01215 & 0.01874 & 0.01013 \\
\hline $\begin{array}{l}\text { Physical capital price } \\
\text { (Px2) }\end{array}$ & 0.05402 & 0.01536 & 0.05567 & 0.02289 & 0.03947 & 0.01825 \\
\hline Fund price (Px3) & 0.0304 & 0.00781 & 0.03163 & 0.0098 & 0.03094 & 0.01216 \\
\hline
\end{tabular}


Table 3. Continued.

\begin{tabular}{|l|c|r|r|r|r|r|}
\hline \multicolumn{1}{|c|}{ Variables } & \multicolumn{2}{c|}{2014} & \multicolumn{2}{c|}{2015} & \multicolumn{2}{c|}{2016} \\
\hline Mean & $\begin{array}{l}\text { Standard } \\
\text { deviation }\end{array}$ & Mean & $\begin{array}{l}\text { Standard } \\
\text { deviation }\end{array}$ & Mean & $\begin{array}{l}\text { Standard } \\
\text { deviation }\end{array}$ \\
\hline Return on equity (y1) & 0.14504 & 0.05837 & 0.17278 & 0.09161 & 0.19364 & 0.05272 \\
\hline $\begin{array}{l}\text { Ratio of total loans to } \\
\text { total assets (x1) }\end{array}$ & 0.65366 & 0.10338 & 0.59764 & 0.15647 & 0.65273 & 0.10592 \\
\hline $\begin{array}{l}\text { Ratio of deposits } \\
\text { reserve to total } \\
\text { deposits (x2) }\end{array}$ & 0.15116 & 0.06205 & 0.16135 & 0.05891 & 0.14648 & 0.0432 \\
\hline $\begin{array}{l}\text { Credit report overdue } \\
\text { (x3) }\end{array}$ & 0.03591 & 0.01964 & 0.04098 & 0.0261 & 0.04249 & 0.02708 \\
\hline Labor price (Px1) & 0.01786 & 0.00802 & 0.01726 & 0.00737 & 0.01497 & 0.00605 \\
\hline $\begin{array}{l}\text { Physical capital price } \\
\text { (Px2) }\end{array}$ & 0.04009 & 0.0189 & 0.03733 & 0.01532 & 0.03282 & 0.01145 \\
\hline Fund price (Px3) & 0.02063 & 0.00942 & 0.01269 & 0.01055 & 0.0081 & 0.00484 \\
\hline
\end{tabular}

Source: authors calculate.

In the price of inputs Px1 (labor price), Px2 (physical capital price), and PX3 (fund price), the average and standard deviation start to decrease during 2014-2016 see table 3, and this period is considered when banks have started to reduce labor costs and increase the efficiency of services.

\section{CREDIT RISK EFFICIENCY ANALYSIS}

For the credit risk assessment of banks in our sample, the results are derived from financial reports. They are oriented to the DEA model, where we evaluated the technical efficiency of credit risk (CR-TE), Credit Risk Allocation Efficiency (CR-AE), and Credit Risk Cost Efficiency (CR-CE). Table 4 shows the results calculated according to the DEA model for all banks operating in Kosovo.

According to the data, Procredit Bank (PCB), by 2015, was the most efficient in all types of efficiency, while in 2016, there was a slight decrease in Raiffeisen Bank (RBKO). Regarding the efficiency shown in the table, we note high technical efficiency while allocative and cost efficiency have fluctuated over the years. In 2015 we noted that all banks had demonstrated high technical efficiency because they are equal to 1 . We see a massive change in all types of efficiency at TEB Bank where there was low operation during 2008-2010, but during 2014-2016 it reached full efficiency in all efficiency types (see table 4). We see this efficiency increase in National Commercial Bank (BKT), Private Business Bank (BPB), and Banka Ekonomike (B.E.). It should also be noted that during the period 2008, the banks TEB and BKT entered the market and failed to attract enough customers. Therefore, they showed low efficiency.

Based on the average for efficiency, we can say that PCB and RBKO had good credit risk management and consistent performance during the study period. The excellent performance of PCB and RBKO bank efficiency compared to other banks is that they are different in terms of capital size and that they are the first banks to enter the market and have their advantages ranging from service delivery, trust to public and market participation. 
Table 4. Credit Risk Technical Efficiency, Credit Risk Allocation Efficiency, Credit Risk Cost Efficiency.

\begin{tabular}{|c|c|c|c|c|c|c|c|c|c|c|}
\hline \multicolumn{11}{|c|}{ Credit Risk Technical Efficiency (CR - TE) } \\
\hline DMU's & 2008 & 2009 & 2010 & 2011 & 2012 & 2013 & 2014 & 2015 & 2016 & Means \\
\hline Raiffeisen Bank (RBKO) & 0.797 & 0.52 & 1 & 1 & 1 & 1 & 1 & 1 & 0.711 & 0.892 \\
\hline Procredit Bank (PCB) & 0.858 & 1 & 1 & 1 & 1 & 1 & 0.871 & 1 & 0.695 & 0.936 \\
\hline NLB Bank (NLB) & 0.494 & 0.64 & 0.688 & 0.803 & 0.816 & 0.485 & 0.942 & 1 & 0.782 & 0.739 \\
\hline $\begin{array}{l}\text { Turk Ekonomi Bankasi } \\
\text { (TEB) }\end{array}$ & 0.003 & 0.002 & 0.124 & 0.568 & 1 & 0.784 & 1 & 1 & 1 & 0.609 \\
\hline $\begin{array}{l}\text { Banka Tregtare Kombëtare } \\
\text { (BKT) }\end{array}$ & 0.017 & 0.006 & 0.49 & 0.945 & 0.293 & 0.034 & 1 & 1 & 0.414 & 0.467 \\
\hline $\begin{array}{l}\text { Banka Privte e Biznesit } \\
\text { (BPB) }\end{array}$ & 1 & 0.465 & 0.444 & 0.007 & 0.021 & 0.031 & 1 & 1 & 1 & 0.552 \\
\hline Banka Ekonomike (B.E.) & 1 & 0.539 & 0.003 & 0.159 & 0.021 & 1 & 0.597 & 1 & 1 & 0.591 \\
\hline Means & 0.596 & 0.453 & 0.536 & 0.64 & 0.593 & 0.619 & 0.916 & 1 & 0.8 & 0.684 \\
\hline \multicolumn{11}{|c|}{ Credit Risk Allocation Efficiency (C.R. - A.E.) } \\
\hline DMU's & 2008 & 2009 & 2010 & 2011 & 2012 & 2013 & 2014 & 2015 & 2016 & Means \\
\hline Raiffeisen Bank (RBKO) & 0.933 & 0.662 & 0.488 & 0.765 & 0.788 & 0.982 & 1 & 0.708 & 0.824 & 0.794 \\
\hline Procredit Bank (PCB) & 0.908 & 1 & 1 & 1 & 1 & 1 & 0.842 & 0.735 & 0.809 & 0.922 \\
\hline NLB Bank (NLB) & 0.933 & 0.623 & 0.712 & 0.621 & 0.791 & 0.734 & 0.623 & 0.525 & 0.798 & 0.707 \\
\hline $\begin{array}{l}\text { Turk Ekonomi Bankasi } \\
\text { (TEB) }\end{array}$ & 0.764 & 0.482 & 0.428 & 0.964 & 0.961 & 0.823 & 1 & 1 & 1 & 0.825 \\
\hline $\begin{array}{l}\text { Banka Tregtare Kombëtare } \\
\text { (BKT) }\end{array}$ & 0.345 & 0.79 & 0.845 & 0.725 & 0.485 & 0.517 & 0.691 & 0.739 & 0.942 & 0.675 \\
\hline $\begin{array}{l}\text { Banka Privte e Biznesit } \\
\text { (BPB) }\end{array}$ & 1 & 0.615 & 0.688 & 0.614 & 0.566 & 0.616 & .829 & .717 & 1 & 0.738 \\
\hline Banka Ekonomike (B.E.) & 0.97 & 0.696 & 0.842 & 0.706 & 0.651 & 0.82 & 0.873 & 0.845 & 0.898 & 0.811 \\
\hline Means & 0.836 & 0.695 & 0.715 & 0.771 & 0.749 & 0.785 & 0.837 & 0.753 & 0.896 & 0.782 \\
\hline \multicolumn{11}{|c|}{ Credit Risk Cost Efficiency (C.R. - C.E.) } \\
\hline DMU's & 2008 & 2009 & 2010 & 2011 & 2012 & 2013 & 2014 & 2015 & 2016 & Means \\
\hline Raiffeisen Bank (RBKO & 0.743 & 0.344 & 0.488 & 0.765 & 0.788 & 0.982 & 1 & 0.708 & 0.586 & 0.712 \\
\hline Procredit Bank (PCB) & 0.779 & 1 & 1 & 1 & 1 & 1 & 0.871 & 0.735 & 0.562 & 0.883 \\
\hline NLB Bank (NLB) & 0.461 & 0.398 & 0.49 & 0.499 & 0.645 & 0.356 & 0.942 & 0.525 & 0.625 & 0.549 \\
\hline $\begin{array}{l}\text { Turk Ekonomi Bankasi } \\
\text { (TEB) }\end{array}$ & 0.002 & 0.001 & 0.053 & 0.548 & 0.961 & 0.645 & 1 & 1 & 1 & 0.579 \\
\hline $\begin{array}{l}\text { Banka Tregtare Kombëtare } \\
\text { (BKT) }\end{array}$ & 0.006 & 0.005 & 0.414 & 0.685 & 0.142 & 0.018 & 1 & 0.739 & 0.39 & 0.378 \\
\hline $\begin{array}{l}\text { Banka Privte e Biznesit } \\
\text { (BPB) }\end{array}$ & 1 & 0.286 & 0.305 & 0.004 & 0.012 & 0.019 & 1 & 0.717 & 1 & 0.483 \\
\hline Banka Ekonomike (B.E.) & 0.97 & 0.375 & 0.002 & 0.112 & 0.014 & 0.82 & 0.597 & 0.845 & 0.898 & 0.515 \\
\hline Means & 0.566 & 0.344 & 0.393 & 0.516 & 0.509 & 0.549 & 0.916 & 0.753 & 0.723 & 0.585 \\
\hline
\end{tabular}

Source: Authors Calculate.

Note: R.K. - T.E. $=$ Credit Risk Technical Efficiency,

R.K. - A.E. = Credit Risk Allocation Efficiency,

R.K. - C.E. = Credit Risk Cost Efficiency

Note: R.K. - T.E. $=$ Credit Risk Technical
Efficiency, R.K. - A.E. = Credit Risk Allocation Efficiency, R.K. - C.E. = Credit Risk Cost Efficiency

Comparing the data to the mean, we see that banks in all efficiency types did not have full efficiency. Still, it should be noted that although they had low-cost efficiency, this efficiency did 
not affect the profitability of banks. So if bad loans affect banks' efficiency at the same time, it may have other implications. Based on the DEA model, we understand which bank performs best but can also end up with much lower efficiency if bad loans are increasing. From the presented results, we can see that Kosovo banks show average technical and allocative efficiency while lower results show cost efficiency. Only TEB Bank has had a full increase in efficiency during the study period during 2014-2016. By examining efficiency individually, we find that most banks in general, although having used all inputs during the study period, had difficulty allocating resources showing low technical, allocative, and cost efficiency.

These results are in line with the findings of the authors Batir et al. (2017), who have studied the efficiency of Turkish banks. Based on their findings, they have concluded that the main contributor to the cost efficiency of Turkish banks is technical efficiency. The findings on credit risk efficiency are in line with Isik \& Hassan (2002a), authors for Turkish banks, who concluded that there is a weak link between cost efficiency and technical efficiency and have suggested that high technical efficiency can be achieved with lower cost. According to the authors, increasing the technical efficiency in the allocation and utilization of resources can improve cost-efficiency.

Many studies on bank efficiency assessment have used approaches that have been divided into two phases, such as Grigorian \& Manole (2002), Casu \& Molyneux (2003), (Pasiouras, 2008a), Saha et al. (2015), Batir et al. (2017).

In the first phase, the efficiency is evaluated based on the DEA model. Whereas in the second stage, the results obtained from DEA are entered as dependent variables in the Tobit regression to determine the efficiency.

Table 5. Tobit regression values for commercial banks of Kosovo.

\begin{tabular}{|c|c|c|c|}
\hline Independent Variables & \multicolumn{3}{|c|}{ Dependent Variables } \\
\hline & $\mathrm{TE}$ & $\mathrm{AE}$ & $\mathrm{CE}$ \\
\hline Const & $0.00076^{* * *}$ & $<0.00001^{* * *}$ & $<0.00001^{* * *}$ \\
\hline Profitability & $\begin{array}{r}0.40381 \\
(0.573425) \\
\end{array}$ & $\begin{array}{r}0.22395 \\
(0.512931) \\
\end{array}$ & $\begin{array}{l}0.06147^{*} \\
(1.21233) \\
\end{array}$ \\
\hline Capital adequacy & $\begin{array}{r}<0.00001^{* * *} \\
(2.30774) \\
\end{array}$ & $\begin{array}{r}<0.00001^{* * *} \\
(0.754966) \\
\end{array}$ & $\begin{array}{r}0.06728^{*} \\
(-0.368099) \\
\end{array}$ \\
\hline Expenses & $\begin{array}{r}0.05103^{*} \\
(-1.40637) \\
\end{array}$ & $\begin{array}{r}0.0007^{* * *} \\
(-1.62488)\end{array}$ & $\begin{array}{r}0.36631 \\
(1.33396)\end{array}$ \\
\hline Deposits & $\begin{array}{r}0.28402 \\
(0.119695) \\
\end{array}$ & $\begin{array}{r}0.345 \\
(0.0761968) \\
\end{array}$ & $\begin{array}{r}0.02481^{* *} \\
(-0.251488) \\
\end{array}$ \\
\hline Loans & $\begin{array}{r}0.0441^{* *} \\
(0.406523)\end{array}$ & $\begin{array}{r}0.09422^{*} \\
(-0.176516) \\
\end{array}$ & $\begin{array}{r}<0.00001^{* * * *} \\
(2.09456) \\
\end{array}$ \\
\hline Non-performing loans & $\begin{array}{r}0.04999^{* *} \\
(0.769633) \\
\end{array}$ & $\begin{array}{r}0.66922 \\
(0.367877) \\
\end{array}$ & $\begin{array}{r}0.83838 \\
(0.079891) \\
\end{array}$ \\
\hline Size & $\begin{array}{r}0.1786 \\
(0.879109) \\
\end{array}$ & $\begin{array}{r}0.08159^{*} \\
(-0.0130705) \\
\end{array}$ & $\begin{array}{r}0.6062 \\
(0.335836) \\
\end{array}$ \\
\hline GDP & $\begin{array}{r}0.05321^{*} \\
(-0.136384)\end{array}$ & $\begin{array}{r}0.4447 \\
(-0.0328983) \\
\end{array}$ & $\begin{array}{r}0.37064 \\
(-0.0607368)\end{array}$ \\
\hline Inflation & $\begin{array}{r}0.968689 \\
(0.000979688) \\
\end{array}$ & $\begin{array}{r}0.18218 \\
(0.0205508) \\
\end{array}$ & $\begin{array}{r}0.20125 \\
(-0.0297955) \\
\end{array}$ \\
\hline
\end{tabular}

Sours: Authors' calculations.

- Significance levels $1 \%$ respectively for the zero correlation tests for the nonparametric limit

- Significance levels 5\% respectively for the zero correlation tests for the nonparametric limit

- Significance levels $10 \%$ respectively for the zero correlation tests for the nonparametric limit. 
This procedure is used because Tobit regression has 0 (zero) as a censored left and 1 (one) as a fair censor of efficiency regression to credit risk management to internal and external factors including the return of assets, return on equity, deposits, expenses, loans, nonperforming loans, bank size, GDP growth, and inflation. This regression examines the relationship between credit risk management and efficiency. Based on previous studies and the Tobit regression analysis results, we can conclude what impact the bank's internal financial factors and external economic factors have on credit risk efficiency.

Based on the results of table 5 , we note that there is a positive relationship between profitability (return on assets) and technical and allocative efficiency but not statistically significant. Still, there is a statistically fragile relationship between profitability and costefficiency. These results are in line with the findings of Altunbas with co-authors who have concluded that return on an asset over the efficiency measures in Japanese banks is not statistically significant. (Altunbas et al., 2000). There is a statistically stable relationship between return on assets and Turkish banks' efficiency in Isik and Hassan's (2002b) research on bank efficiency in Turkey. Positive links have also been found by the authors Pasiouras (2008b) in Greek banks; Sufian \& Noor (2009) in the Mena and Asian regions during 2001-2006; and Adusei (2016) in the Ghanaian banking region. Based on these studies, both deposit and credit clients prefer banks with high returns on assets, so banks gain the best possible customers.

Contrary to these results are the authors Ataullah \& Le (2006), in their study of Banks of India, who reported a negative relationship between return on asset and efficiency and emphasized that the relation between these variables depends on the model specification, and the author Kepkova (2015), who, in his study of Greek banks, found that return on assets has a negative effect on bank efficiency. The same negative relationship between return on assets and all types of efficiency has also been found by Batir et al. (2017), who studied Turkish banks.

Second, in our research's second internal financial factor, we found that the capital adequacy ratio has a positive correlation with a statistical significance of 0.001 in technical and allocative efficiency. In cost efficiency, there is a weak negative relationship. The results support earlier research that well-capitalized banks face fewer risks and have greater flexibility in dealing with problems. These results are consistent with the studies of Lozano-vivas et al. (2016), Grigorian \& Manole (2002), Pasiouras (2008b), Řepkova (2015), Wahab et al. (2017), who have found that banks with adequate capitalization can be technically efficient, allocative and costefficient. However, contrary to these results which have found negative associations are the authors Isik \& Hassan (2002b), Akhigbe \& McNulty (2005), Sufian \& Noor (2009), Chortareas et al. (2011), Adusei (2016), and Batir et al. (2017), who in their findings refuted the assumption that good bank capitalism is a good predictor of efficiency.

Third, from the results, we conclude that expenditures for commercial banks of Kosovo are negatively correlated with statistical significance in technical and allocative efficiency while having a positive relationship with cost efficiency but not statistically significant. These results are similar to the findings of the authors Berger \& Mester (1997), Mokhtar et al. (2007), and Batir et al. (2017); as we find these results, we can say that with increasing costs, it may be less efficient to use inputs in specific directions. Banks achieve more outstanding technical and cost-efficiency by reducing costs. The authors who found an excellent relationship between expenditure and T.E., A.E., C.E. are Mohamad Noor \& Nor Hayati (2012) and Ismail et al. (2013), who conclude that increased spending affects increased technical, allocative, and cost efficiency.

Fourth, deposits have shown a positive relationship between technical and allocative efficiency but without statistical significance, but there is a negative relationship between deposits in cost efficiency. Based on this result and according to Batir et al. (2017), if there is a high ratio of deposits to assets, it can cause banks to have low technical and allocative efficiency, but it will have a high cost-efficiency. The author also found that participating banks have a negative relationship, whereas, in conventional banks, only a positive relationship with cost efficiency has been found (Batir et al., 2017). 
Fifth, there is a positive relationship between credit and technical efficiency and cost, while allocative efficiency has a weak negative statistical significance. The authors who have found this positive link in their research are Berger \& Mester (1997), Grigorian \& Manole (2002), Isik \& Hassan (2002b), Pasiouras (2008b), Sufian \& Noor (2009), Saha et al. (2015) and Batir et al., (2017). They have pointed out that the higher the number of loans, the higher the banking activity in technical and cost-efficiency. Simultaneously, the authors who found a negative relationship between credit and efficiency are the author Havrylchyk (2006), who stated that credit reduction affects efficiency reduction.

Sixth, based on the results, non-performing loans show a statistically positive relationship with technical efficiency and not statistically with allocative and cost-efficiency. Similar results obtained by Tobit regression that found a positive relationship between NPLs and efficacy are the authors' Fan \& Shaffer (2004), Karim et al. 2010), and Batir et al. (2017), who pointed out that if there is a positive relationship between NPLs and efficiency, then banks are not good at solving problems. Also, banks that tend to make loan assessments or produce high-risk loans can be labeled as efficient by comparing them with banks that ensure their loans are qualitative (Mester, 1996). Some studies statistically support a negative relationship between nonperforming loans and bank efficiency, such as Berger \& DeYoung (1997). According to the aforementioned authors, the growth of bad loans causes a low level of efficiency. Also, the negative relationship between NPLs and bank efficiency the following authors have found in their studies: Mokhtar et al. (2007), Pasiouras (2008), Ismail et al. (2013), Saha et al. (2015), and Wahab et al. (2017).

Seventh, based on the findings, banks' size as an internal financial factor has a statistically very weak negative relationship with allocative efficiency and a positive relationship but no statistical significance with technical and costefficiency. This result is consistent with the results of the authors Grigorian \& Manole (2002), Havrylchyk (2006), Ataullah \& Le (2006), and Batir et al. (2017). Some studies have found that bank size has positive statistical correlations with bank efficiency, Mokhtar et al. (2007), Sufian et al. (2009), Ismail et al. (2013), Rosman et al. (2014), Saha et al. (2015), (Adusei, 2016), Wahab et al., (2017). These authors conclude that banks that own large capital are more profitable because using advanced technology minimizes their costs.

Eighth, based on empirical findings, we find that GDP has a statistically weak negative relationship with technical efficiency. In contrast, with allocative and cost efficiency, this relationship is positive but without any statistical significance, which we conclude that GDP does not affect efficiency on Kosovo's commercial banks. Similar results have also been found in earlier studies from Ataullah \& Le (2006), Hasan et al. (2009), Thoraneenitians \& Avkiran (2009), Vu \& Nahm (2013), kovepková (2015), Batir et al. (2017). While the authors Wahab et al. (2017), Sufian et al. (2009), in their studies, found that GDP has a statistically significant positive relationship with bank credit efficiency.

Finally, we see that inflation has no impact on bank efficiency because the results show that it has no statistical significance with bank efficiency. Similar results were also found by the authors Grigorian \& Manole (2002), Vu \& Nahm (2013), who found that by lowering inflation rates, banks could increase their profits as well. Wahab et al. (2017) and Batir et al. (2017) came to the same conclusions and stating that rising inflation affects lower bank and credit efficiency.

\section{CONCLUSION}

Based on the mean, this study has shown that Kosovo's commercial banks during this study period had more allocative efficiency than technical and cost-efficiency. On this basis, it can be said that banks operated with a lower capacity of efficiency because they did not utilize all inputs at full capacity to increase their productivity and increase cost-efficiency. Improving further the technical efficiency would make Kosovo's banks provide better and timely services for the customers.

Studying the determinants of bank credit risk efficiency in commercial banks in Kosovo, we used Tobit regression. We found a statistically significant positive relationship between bank 
efficiency, capital adequacy, and credit. In addition, other factors used to measure bank efficiency, including profitability, deposits, spending, and size of banks, GDP growth, and inflation, are not statistically significant. Since capital adequacy and loans have statistically significant positive correlations, we can say that credit risk management's efficiency significantly affects bank efficiency.

Based on Tobit regression results, we determined that there is a positive relationship between profitability and technical and allocative efficiency but not statistically significant. This means that technical and allocative efficiency impacts the profitability levels to some extent. Based on this, we can conclude that banks should allocate more resources to enhance technical and allocative efficiency for better performance.

Still, there is a statistically fragile relationship between profitability and cost-efficiency. Based on this, we can conclude that improving further technical efficiency, allocative efficiency, and cost efficiency may positively impact the level of banks' profitability. Second, we found that the capital adequacy ratio has a positive correlation with a statistical significance within technical and allocative efficiency. In cost efficiency, there is a weak negative relationship. The results are in line with prior research that well-capitalized banks face fewer risks and have greater flexibility in dealing with problems.

Third, from the above results, we conclude that expenditures for commercial banks of Kosovo are negatively correlated with statistical significance in technical and allocative efficiency while positive relation with cost efficiency but not statistically significant. Based on this, we can conclude that with increasing costs, it may be less efficient for banks to use inputs in specific directions. Fourth, positive but not statistically significant results are shown between the deposits and technical and allocative efficiency. On the other hand, deposits and cost efficiency are negatively related. Fifth, our results show that a positive relationship exists between credit and technical efficiency and cost, while allocative efficiency has a weak negative statistical significance.

Sixth, based on the results, non-performing loans show a statistically positive relationship with technical efficiency and not statistically with allocative and cost-efficiency. Seventh, our results show that banks' size as an internal financial factor has a statistically very weak negative relationship with allocative efficiency and a positive relationship but no statistical significance with technical and cost-efficiency. Eighth, based on empirical findings, we find that GDP has a statistically weak negative relationship with technical efficiency. In contrast, with allocative and cost efficiency, this relationship is positive but without any statistical significance, which we conclude that GDP does not affect efficiency on Kosovo's commercial banks. Based on our results, we can conclude that inflation does not impact the level of bank efficiency in Kosovo.

\section{REFERENCES}

Adusei, M. (2016). Determinants of bank technical efficiency: Evidence from rural and community banks in Ghana. Cogent Business \& Management, 3(1). https://doi.org/10.1080/23311975.2016.119 9519

Akhigbe, A., \& McNulty, J. (2005). Profit efficiency sources and differences among small and large U.S. commercial banks. Journal of Economics and Finance. https://doi.org/10.1007/BF02761575

Allen, B., Chan, K. K., Milne, A., \& Thomas, S. (2012). Basel III: Is the cure worse than the disease?. International Review of Financial Analysis, 25, 159-166.

Altman, E. I., \& Saunders, A. (1997). Credit risk measurement: Developments over the last 20 years. Journal of Banking \& Finance, 21, 1721-1742. https://doi.org/10.1016/S03784266(97)00036-8

Altunbaş, Y., Gardener, E. P. M., Molyneux, P., \& Moore, B. (2001). Efficiency in European banking. European Economic Review, 45(10), 1931-1955. https://doi.org/10.1016/S00142921(00)00091-X

Altunbas, Y., Liu, M. H., Molyneux, P., \& Seth, R. (2000). Efficiency and risk in Japanese banking. Journal of Banking and Finance. https://doi.org/10.1016/S03784266(99)00095-3 
Ataullah, A., \& Le, H. (2006). Economic reforms and bank efficiency in developing countries : the case of the Indian banking industry Economic reforms and bank efficiency in developing countries : the case of the Indian banking industry. Applied Financial Economics, 16(November 2013), 37-41. https://doi.org/10.1080/0960310050040744 0

Ben Rejeb, A., \& Boughrara, A. (2013). Financial liberalization and stock markets efficiency: New evidence from emerging economies. Emerging Markets Review. https://doi.org/10.1016/j.ememar.2013.09.0 01

Berger, A. N., \& DeYoung, R. (1997). Problem loans and cost efficiency in commercial banks. Journal of Banking and Finance. https://doi.org/10.1016/S03784266(97)00003-4

Berger, A. N., \& Humphrey, D. B. (1997). Efficiency of financial institutions: International survey and directions for future research. European Journal of Operational Research, 98(2), 175-212. https://doi.org/10.1016/S03772217(96)00342-6

Berger, A. N., \& Mester, L. J. (1997). Inside the black box: What explains differences in the efficiencies of financial institutions? Journal of Banking and Finance. https://doi.org/10.1016/S03784266(97)00010-1

Blejer, M. I. (2006). Economic growth and the stability and efficiency of the financial sector. Journal of Banking \& Finance, 3012), 3429-3432.

https://doi.org/http://dx.doi.org/10.1016/j.jb ankfin.2006.06.001

Casu, B., \& Molyneux, P. (2003). A comparative study of efficiency in European banking. Applied Economics, 35(17), 1865-1876. https://doi.org/10.1080/0003684032000158 109

Chauhan, R., \& Kaur, H. (2015). Predictive Analytics and Data Mining. In Business Intelligence. https://doi.org/10.4018/978-14666-9562-7.ch019

Chen, K., \& Pan, C. (2012). An empirical study of credit risk efficiency of banking industry in
Taiwan. Web Journal of Chinese

Management Review, 15(1), 1-16. Retrieved from

http://cmr.ba.ouhk.edu.hk/cmr/webjournal/ v15n1/CMR326E11.pdf

Chortareas, G. E., Girardone, C., \& Ventouri, A. (2011). Financial frictions, bank efficiency and risk: Evidence from the eurozone. Journal of Business Finance and Accounting. https://doi.org/10.1111/j.14685957.2010.02226.x

Ding, H., Wang, Z., \& Wu, Y. (2017). Tobit regression model with parameters of increasing dimensions. Statistics and Probability Letters. https://doi.org/10.1016/j.spl.2016.09.006

E U R.O. P E A N C E N T R A L B A N K FINANCIAL STABILITY REVIEW dECEMBER 2009. (2009), (dECEmBER).

Eichengreen, B., \& Baldwin, R. (2008). What G20 leaders must do to stabilise our economy and fix the financial system. VoxEU. org Publication. Retrieved from http://www.voxeu.org/reports/G20_Summit .pdf

Eyceyurt Batir, T., Volkman, D. A., \& Gungor, B. (2017b). Determinants of bank efficiency in Turkey: Participation banks versus conventional banks. Borsa Istanbul Review, 172), 86-96.

https://doi.org/10.1016/j.bir.2017.02.003

Fan, L., \& Shaffer, S. (2004). Efficiency versus risk in large domestic U.S. banks. Managerial Finance, 30(9), 1-19. https://doi.org/10.1108/0307435041076924 5

George Assaf, A., Matousek, R., \& Tsionas, E. G. (2013). Turkish bank efficiency: Bayesian estimation with undesirable outputs. Journal of Banking and Finance, 372), 506517.

https://doi.org/10.1016/j.jbankfin.2012.09.0 09

Grigorian, D. A., \& Manole, V. (2002). Determinants of Commercial Bank Performance in Transition: An Application of Data Envelopment Analysis. IMF Working Papers. https://doi.org/10.5089/9781451856651.00 1 
Hasan, I., Wachtel, P., \& Zhou, M. (2009). Institutional development, financial deepening and economic growth: Evidence from China. Journal of Banking and Finance. https://doi.org/10.1016/j.jbankfin.2007.11.0 16

Havrylchyk, O. (2006). Efficiency of the Polish banking industry: Foreign versus domestic banks. Journal of Banking and Finance. https://doi.org/10.1016/j.jbankfin.2005.07.0 09

Isik, I., \& Hassan, M. K. (2002a). Cost and profit efficiency of the turkish banking industry: An empirical investigation. Financial Review, 372), 257-279. https://doi.org/10.1111/1540-6288.00014

Isik, I., \& Hassan, M. K. (2002b). Technical, scale and allocative efficiencies of Turkish banking industry. Journal of Banking and Finance, 26(4), 719-766. https://doi.org/10.1016/S03784266(01)00167-4

Ismail, F., Shabri Abd. Majid, M., \& Rahim, R. A. (2013). Efficiency of Islamic and conventional banks in Malaysia. Journal of Financial Reporting and Accounting. https://doi.org/10.1108/jfra-03-2013-0011

Iveta, $\check{R}$. (2015). Banking Efficiency Determinants in the Czech Banking Sector. Procedia Economics and Finance, 23(October 2014), 191-196. https://doi.org/10.1016/S22125671(15)00367-6

Jiménez, G., \& Saurina, J. (2006). Credit Cycles, Credit Risk, and Prudential Regulation. International Journal of Central Banking, 2(January), 65-98. https://doi.org/10.1227/01.NEU.0000349921 $.14519 .2 \mathrm{~A}$

Karim, M. Z. A., Chan, S. G., \& Hassan, S. (2010). Bank efficiency and non-performing loans: Evidence from malaysia and Singapore. Prague Economic Papers. https://doi.org/10.18267/j.pep.367

Liu, J. S., Lu, L. Y. Y., Lu, W. M., \& Lin, B. J. Y. (2013). Data envelopment analysis 19782010: A citation-based literature survey. Omega (United Kingdom). https://doi.org/10.1016/j.omega.2010.12.00 6
Lozano-vivas, A. A. N. A., Pastor, J. T., \& Pastor, J. M. (2016). An Efficiency Comparison of European Banking Systems Operating under Different Environmental Conditions. Journal of Productivity Analysis, 18(1), 59-77.

McCue, C., \& McCue, C. (2015). Chapter 1 Basics. In Data Mining and Predictive Analysis. https://doi.org/10.1016/B978-012-800229-2.00001-8

Mehmeti, F. (2019). The CBK is meeting best international financial regulation standards. Retrieved from https://bqkkos.org/mehmeti-the-cbk-is-meeting-bestinternational-financial-regulationstandards/?lang=en

Mester, L. J. (1996). A study of bank efficiency taking into account risk-preferences. Journal of Banking and Finance. https://doi.org/10.1016/03784266(95)00047-X

Mohamad Noor, M., \& Nor Hayati, A. (2012). The Determinants of World Islamic Banks' Efficiency: Does Country Income Level have an Impact? Journal of Islamic Economics, Banking and Finance.

Mokhtar, H. S. A., Abdullah, N., \& Alhabshi, S. M. (2007). Technical and Cost Efficiency of Islamic Banking in Malaysia. Review of Islamic Economics.

Omankhanlen, Alex, E. (2012). The Role of Banks in Capital Formation and Economic Growth: The Case of Nigeria. Economy Transdisciplinarity Cognition, 5(103), 103112. Retrieved from www.ugb.ro/etc

Pasiouras, F. (2008a). Estimating the technical and scale efficiency of Greek commercial banks: The impact of credit risk, off-balance sheet activities, and international operations. Research in International Business and Finance, 22(3), 301-318. https://doi.org/10.1016/j.ribaf.2007.09.002

Pasiouras, F. (2008b). Estimating the technical and scale efficiency of Greek commercial banks: The impact of credit risk, off-balance sheet activities, and international operations. Research in International Business and Finance, 22(3), 301-318. https://doi.org/10.1016/j.ribaf.2007.09.002

Peek, J., \& Rosengren, E. S. (2012). The Role of Banks in the Transmission of Monetary 
Policy. In The Oxford Handbook of Banking. https://doi.org/10.1093/oxfordhb/97801996 40935.013.0010

Psillaki, M., Tsolas, I. E., \& Margaritis, D. (2010). Evaluation of credit risk based on firm performance. European Journal of Operational Research, 201(3), 873-881. https://doi.org/10.1016/j.ejor.2009.03.032

Rosman, R., Wahab, N. A., \& Zainol, Z. (2014). Efficiency of Islamic banks during the financial crisis: An analysis of Middle Eastern and Asian countries. Pacific Basin Finance Journal. https://doi.org/10.1016/j.pacfin.2013.11.001

Saha, A., Ahmad, N. H., \& Dash, U. (2015). Drivers of technical efficiency in Malaysian banking: A new empirical insight. Asian-Pacific Economic Literature, 29(1), 161-173. https://doi.org/10.1111/apel.12091

Sufian, F., Akbar, M., \& Mohamad, N. (2009). The determinants of Islamic banks' efficiency changes Empirical evidence from the MENA and Asian banking sector. International Journal of Islamic and Middle Eastern Finance and Management, 2(2), 120-138. https://doi.org/10.1108/1753839091096514 9

Thoraneenitiyan, N., \& Avkiran, N. K. (2009). Measuring the impact of restructuring and country-specific factors on the efficiency of post-crisis East Asian banking systems: Integrating DEA with SFA. Socio-Economic Planning Sciences. https://doi.org/10.1016/j.seps.2008.12.002

Toçi, V. Z. (2009). Efficiency of banks in SouthEast Europe : With special reference to Kosovo. Central Bank of Kosovo Working Paper, (4).

Vu, H., \& Nahm, D. (2013). The determinants of profit efficiency of banks in Vietnam. Journal of the Asia Pacific Economy. https://doi.org/10.1080/13547860.2013.803 847

Wahab N., Rosman R., dhe Z. Z. (2017). HOW EFFICIENT WERE ISLAMIC BANKS DURING THE FINANCIAL CRISIS ? EMPIRICAL EVIDENCE FROM ASIAN. Intellectual Economics, 11(1), 44-62. https://doi.org/10.13165/IE-17-11-1-04

\section{CORRESPONDING AUTHOR}

Arben Sahiti, email: arben.sahiti@uni-gjilan.net 